\title{
IMMANUEL KANT EN DIE IDEOLOGIESE DENKE VAN DIE NEGENTIENDE EEU
}

\section{P. S. DREYER}

Immanuel Kant is op 22 April 1724 in Königsberg (Pruise) gebore. Dit is dus vanjaar (1974) die twee honderd en vyftigste herdenking van sy geboortejaar. Hierdie artikel is bedoel om die geboortedag van een van die grotes onder die grootste filosowe van die wêreld nie ongemerk in Suid-Afrika te laat verbygaan nie.

Ideologieë, by uitstek die Fascisme, Nasionaal-Sosialisme en die Kommunisme, het in die E2O ontsaglike probleme en namelose ellende tot gevolg gehad. Die Tweede Wêreldoorlog het die Fascisme en die Nasionaal-Sosialisme byna heeltemal uitgewis en die twee woorde feitlik nog net laat oorbly as handige en effektiewe skelwoorde waarmee ' $n$ mens jou politieke opponente kan probeer vermorsel. Daarteenoor is die Kommunisme gedurende die Tweede Wêreldoorlog deur die Weste tot ' $n$ magsposisie gehelp en hang dit soos 'n onheilspellende onweerswolk oor ' $n$ siek en verlamde Weste - 'n onweerswolk wat steeds donkerder en dreigender word.

Dit op sigself is ' $n$ wye probleemveld vir die wysbegeerte. Daarmee saam word die hedendaagse wysbegeerte in wye kringe intens besig gehou met die verskynsel van ideologiese denke as sodanig. Wanneer ons van ideologiese denke praat, bedoel ons die soort denkaktiviteit wat nie primêr deur die vereistes van wetenskaplikheid gelei word nie, maar deur die vereistes van ' $n$ bepaalde ideologie.

Wat sopas gesê is, maak alreeds 'n teenstelling tussen wetenskaplike en ideologiese denke. Baie aanhangers van bepaalde ideologieë sal hiermee geensins instem nie, omdat hulle juis vir hulle werk aanspraak op wetenskaplike fundering en uitbouing maak. Daarnaas kry ons nog ander skerp verskille oor die aard en die noodsaaklikheid of vermybaarheid van ideologieë en ideologiese denke. Op die hele diskussie kan ons hier nie ingaan nie, maar dit plaas ons wel voor die taak om baie kortliks die wesenskenmerke van 'n ideologie aan te dui ${ }^{2}$ ): -

In die laaste instansie berus elke ideologie op bepaalde waardes en diepste oortuigings wat vir die aanhangers van die ideologie geldig is. Hierdie waardes en oortuigings is nie 'n besluit wat na wetenskaplike ondersoek bereik word nie en is ook nie wetenskaplik bewysbaar nie. Dit leef in die gemoed, word deur tradisie en opvoeding oorgedra en is baie dikwels van dieselfde aard en selfs 
ten nouste gemoeid met godsdienstige geloof. Sulke waardes en oortuigings is bv. die geloof aan die waarde en roeping van die volk, die noodsaaklikheid van 'n absolute staat vir die persoonlike voortbestaan, die roeping van die proletariaat as bevryder van die mensheid en so meer.

Daarmee is die verskil tussen ideologie en wetenskap ook al aangedui, want die wetenskaplike uitspraak is nie waardebepaald nie, dit is voorlopig en hipoteties van aard, dit moet verifieerbaar en volgens wetenskaplike metodes verkry wees en handhaaf 'n metafisiese gedistansieerdheid.

Wat oor ideologie gesê is, toon egter 'n groot ooreenkoms met lewensopvatting. Inderdaad is dit so dat die waardes en oortuigings waarop die ideologie gebou is, elemente van die lewensopvatting is en dit is die grond van die sterk ooreenkoms tussen lewensopvatting en ideologie. Deur die belangrikste ooreenkomste en verskille te stel kan ons die wese van die ideologie duidelik maak:

1. Beide lewensopvatting en ideologie is in die laaste instansie 'n aangeleentheid van hoogste waardes en diepste oortuigings wat deur tradisie oorgedra word en wat die mens tot sy eie maak nie op grond van wetenskaplike, rasionele bewysvoeringe nie, maar deur eksistensiële beslissing en aanvaarding. Hieruit vloei 'n lewenshouding, 'n stellingname in en teenoor die wêreld en ' $n$ rangorde van waardes en norme. Die verskil wat ons egter in hierdie verband moet beklemtoon, is dat die lewensopvatting allesomvattend is, terwyl die ideologie selektief is. Die omvattendheid van die lewensopvatting blyk daaruit dat die mens in sy gehele handel en wandel gelei word deur voor-en afkeure, deur keuses wat op 'n rangorde van waardes berus en deur die rigsnoere van norme wat die krag van behoorlikheidseise het - en dit alles grond in die lewensopvatting wat 'n mens huldig. Die ideologie daarenteen bou net op sekere waardes en norme, sodat mense van verskillende lewensopvattings nog steeds dieselfde ideologie kan aanhang. So kan Christen en ateîs bv. albei ' $n$ ideologie aanhang wat op die geloof in die waarde en roeping van die eie volk gebou is. Dit is waarom Lamprecht van 'n ideologie praat as 'n .,snypunt van lewensopvattings".

Hierby moet ons egter opmerk dat elke ideologie 'n totalitêre tendens het, m.a.w. dit neig daartoe om allesomvattend te word, sodat alle ander waardes ondergeskik aan die een bepaalde waarde (of enkele waardes as groep) gemaak word en die hele bestaan van die mens in al sy aspekte in terme van die ideologie geînterpreteer word. Verder moet ons die vraag stel of ideologie nie tot lewensopvatting kan word nie. As 'n mens dink aan 'n land soos Rusland, waar die Kommuniste reeds meer as 'n halwe eeu 'n totalitêre be- 
wind voer en alle middele tot indoktrinasie van die bevolking gebruik, is dit ' $n$ ernstige moontlikheid dat die aanvanklike Kommunistiese ideologie in ' $n$ allesomvattende Kommunistiese lewensopvatting verander het.

2. ' $n$ Lewensopvatting is grotendeels onbewus. Dit vorm so'n wesenlike deel van ons menswees, dat ons leef en is soos ons lewensopvatting is. Die lewensopvatting tree te voorskyn in die stellingnames, voor- en afkeure van ons daaglikse bestaan. ' $n$ Lewensopvatting word eers bewus (en dan ook maar net ten dele) wanneer ' $n$ individu, gemeenskap of volk homself bedreig voel deur ' $n$ ander wat ' $n$ verskillende lewensopvatting huldig. - Daarteenoor bestaan daar nie so iets soos ' $n$ onbewuste ideologie nie, soos hieronder duideliker sal blyk.

3. Soos gesê is, word 'n lewensopvatting uitgedruk in die mens se manier van lewe; die lewensopvatting is die grondslag en rigsnoer van die praktiese bestaan. Aan die lewensopvatting word egter geen bepaalde doel, strewe, program of organisasie gekoppel nie. As ' $n$ mens na aanleiding van jou lewensopvatting gevra word na jou doel of na die rede van jou bepaalde lewenswyse, staan jy grotendeels verleë. Die enigste antwoord wat werklik moontlik is, is van die aard: ek lewe so, want so'n lewe is mooi en goed - dit hoort so. Die enigste gedeeltelike uitsondering hierop is weer gevalle van kultuurbedreiging, waar die handhawing van die eie identiteit, taal, ens. ' $n$ bewuste doel kan wees en volgens 'n definitiewe program nagestreef kan word. Daarteenoor koester 'n ideologie 'n bewuste doel. Die nastrewing van die doel vereis die ondersteuning van soveel mense as moontlik; daarom moet ander tot navolgers gemaak word deur oorreding (propaganda ens.), die ideologie moet tot samehangende, verstaanbare sisteem uitgewerk word, daar moet ' $n$ program van aksie en ' $n$ organisasie wees en dit bring 'n bewuste stellingname in terme van die ideologie teenoor mede- en teenstaanders mee.

$\mathrm{Na}$ hierdie inleidende uiteensetting van die aard van ideologie keer ons na Immanuel Kant terug om te probeer naspeur in welke mate sy filosofie die ruimte vir die opkoms van ideologiese denke geskep het.

Kant leef van 1724 tot 1804 . Sy hele lewe val dus in die E18, wat in die geskiedenis van die wysbegeerte as die eeu van die Aufklärung bekend staan. Die wesenskenmerk van die Aufklärung is die opperheerskappy van die mondige mens deur sy rede. Wat dus nie in die menslike rede gegrond kan word of voor die regterstoel van die rede geregverdig kan word nie, het geen aanspraak op erkenning of selfs bestaan nie. 
Hierdie rasionalisme is kenmerkend ook van die filosofiese strominge wat Kant voorafgaan en wat die aanleiding tot sy eie filosofiese stellingname is. Die belangrikste van hierdie strominge was die (Britse) Empirisme en die (Vastelandse) Rasionalisme, wat beide ewe rasionalisties van gees en opset was, maar radikaal uiteengegaan het oor die kwessie van die oorsprong van kennis. Die Empirisme vind die oorsprong van kennis in sintuiglike ervaring wat nie op sintuiglike indrukke teruggevoer kan word nie, het geen aanspraak op geldigheid as betroubare kennis nie. Die Rasionaliste daarteen beskou die sintuiglike kennis as onseker, onpresies, onbetroubaar en hoogstens relatief geldig. Die enigste werklik betroubare en universeel geldige kennis is kennis wat op die rede self berus, d.w.s. die aangebore idees en wat daaruit afgelei kan word. Beide Empirisme en Rasionalisme loop egter op 'n skeptisisme uit: die Empiris kan 'n grenslose massa van feitelike gegewens versamel, maar kan tot universeel geldende, wetenskaplike uitsprake nie kom nie, omdat hy nie rekenskap kan gee van die ordenende prinsipes (universaliteit, kousaliteit, noodsaaklikheid, ens.) van ons kennis nie, aangesien hierdie prinsipes nie deur die sintuiglike ervaring bekom kan word nie. Die Rasionalis daarenteen kan algemeen geldende, absoluut seker uitsprake maak, maar kan sy kennis nooit uitbrei verder as die begrippe wat as aangebore by alle mense aanvaar word nie. In Kant se terminologie: die Empiris se oordele is sinteties, maar kan slegs aposteriori wees; die Rasionalis se oordele is a priories, maar kan slegs analities wees.

In sy Kritik der reinen Vernunft (eerste uitgawe 1781, tweede uitgawe 1787) beskuldig Kant beide die Empiriste en die Rasionaliste (maar veral lg.) van dogmatisme. Dogmatisme is, volgens Kant, die onkritiese aanvaarding van die mens se kenvermoëns. Wat noodsaaklik is, is 'n "Kritik" waarin die aard, bronne en grense van die rede aangetoon word ( $K r V, B \times X X V)$. Kant is skerp krities, maar hoegenaamd nie skepties ingestel nie. Dat kennis moontlik is, word onbetwyfelbaar deur die bestaan en die „sichere Gang“ van die wetenskap aangetoon. Aan die hand van veral die fisika en die wiskunde as voorbeelde toon hy aan dat ons ons kennis van die synde slegs kan opdoen en uitbrei langs die weg van sintuiglike waarneming - dus sintetiese, aposterioriese oordele. (In die geval van die wiskunde het ons te make met "n „reine Anschauung", waarop ons hier nie ingaan nie). Maar juis uit hierdie voorbeelde toon hy ewe onteenseglik aan dat ons in ons wetenskaplike uitsprake gedurig die grense van die ervaring oorskry, m.a.w. dat ons a prioriese (van die ervaring onafhanklike) uitsprake maak wat nogtans sinteties van aard is (d.w.s. ' $n$ uitbreiding van ons kennis insluit). Nog meer: in ons wetenskaplike werk maak ons nie net sinteties a prioriese oordele nie, maar hierdie soort oordele is nood- 
saaklik in wetenskaplike werk en juis daarin vind ons die eg-wetenskaplike uitsprake. Die fundamentele probleem is dus: „Wie sind synthetische Urteile a priori möglich?" (KrV, B 19).

Die oplossing van die probleem soek Kant daarin dat ons weliswaar van die natuur moet leer, maar dat ons nie soos ' $n$ tabula rasa onsself oopstel vir watter indrukke ook al van die natuur afkomstig is nie; ons benader die natuur met die probleme wat ons stel, met die prinsipes waarvolgens ons kenvermoëns funksioneer en met die reëls wat ons aan die natuur oplê. Op die manier dwing ons die natuur om te antwoord net op díe vrae waarop ons ' $n$ antwoord soek. „Die Vernunft musz mit ihren Prinzipien, nach denen allein übereinkommende Erscheinungen für Gesetze gelten können, in einer Hand, und mit dem Experiment, das sie nach jenen ausdachte, in der anderen, an die Natur gehen, zwar um von ihr belehrt zu werden, aber nicht in der Qualität eines Schülers, der sich alles vorsagen läszt, was der Lehrer will, sondern eines bestallten Richters, der die Zeugen nötigt, auf die Fragen zu antworten, die er ihnen vorliegt" (KrV, B XIII). Die a prioriese element in ons wetenskaplike kennis bly fundamenteel onverklaarbaar solank ons aanneem dat ons al ons kennis in al sy aspekte uit die ervaring kry. Om hierdie rede word Kant gedwing tot ' $n$ omkering na die voorbeeld van Kopernikus en wat sedertdien as Kant se Kopernikaanse wending bekend staan ( $\mathrm{KrV}$, B XVI): „Bisher nahm man an, alle unsere Erkenntnis müsse sich nach den Gegenständen richten; aber alle Versuche über sie a priori etwas durch Begriffe auszumachen, wodurch unsere Erkenntnis erweitert würde, gigen unter dieser Voraussetzung zunichte. Man versuche es daher einmal, ob wir nicht in den Aufgaben der Metaphysik damit besser fortkommen, dasz wir annehmen, die Gegenstände müssen sich nach unserem Erkenntnis richten..." - Sedert 1781 is die terminologie baie verander en is baie verfyning en verdieping aangebring, maar die fundamentele standpunt van Kant het in ons beskouing van wetenskaplike kennis vanselfsprekend geword.

Die Kopernikaanse wending bring die kensubjek met sy kenvermoëns prominent na vore. Die kenobjek (.Gegenstände") is vir Kant egter nie vanselfsprekend nie en daarom moet gevra word na wat vir ons in ons kenning gegee is. Hier maak Kant ' $n$ fundamentele onderskeiding tussen Ding an sich en Erscheinung (wat hy in sy etiese geskrifte by voorkeur noumenon en phenomenon noem). Wat ons kan ken, is altyd net die Erscheinung, nooit die Ding an sich nie. In Kant se terminologie: die Ding an sich is transendent ten opsigte van ons kenvermoëns. Nog anders gestel: die a prioriese toerusting wat die voorwaarde van die moontlikheid tot kenning is ( $n l$. die aanskouingsvorme ruimte en tyd en die twaalf kategorieë), is nie op die Ding an sich van toepassing nie. 
Na die verskyning van die Kritik der reinen Vermunft in 1781 word skerp kritiek op die leer van die onkenbaarheid van die Ding an sich uitgeoefen, bv. deur Jacobi. In hoofsaak kom die kritiek op die volgende neer: om te praat van die Ding an sich en allerlei uitsprake daaroor te maak maar nogtans te verklaar dat dit onkenbaar is, is ' $n$ contradictio in terminis. Verder: as ons sê dat die Ding an sich bestaan, beteken dit dat ons die kategorie van substansie daarop toepas; en hoe kan ons die verhouding tussen die Ding an sich en die Erscheinung anders voorstel as deur die kategorie van kousaliteit daarop van toepassing te maak?

Noukeurige oorweging kan nie anders as om toe te gee dat daar meriete in die kritiek is nie. Desnieteenstaande behou Kant die leer van die Ding an sich in die tweede uitgawe van die Kritik der reinen Vernunft (1787), wat toon hoe belangrik dit vir hom was. Die belangrikheid van die Ding an sich vir Kant het hoofsaaklik tweërlei gronde: aan die een kant is die Ding an sich die waarborg vir die realiteit van die objektiewe wêreld; as die Ding an sich verwerp sou word, sou die esse est percipi van Berkeley nie vermy kon word nie. Aan die ander kant (en dit weeg by Kant die swaarste) maak die Ding an sich die sedelike handeling moontlik: Kant aanvaar sonder enige twyfel die algemeen geldige beskouing van sy tyd, $\mathrm{nl}$. dat dit natuur in al sy aspekte volledig onder 'n meganiese wetmatigheid staan, waarvan die wet van oorsaaklikheid die grondslag is. 'n Natuurwet laat geen uitsondering toe nie. Die wet van oorsaaklikheid bepaal dat elke verandering 'n genoegsame oorsaak het en gegewe die oorsaak, moet die verandering as die gevolg van die oorsaak noodwendig intree. Dit is 'n wet geen plek vir vryheid laat nie, terwyl vryheid 'n noodsaaklike voorwaarde vir die sedelike handeling is. Ons het dus 'n antinomie: aan die een kant die onvoorwaardelike geldigheid van die wet van oorsaaklikheid, aan die ander kant die ewe onvoorwaardelike eis van vryheid. Hierdie antinomie los Kant op d.m.v. sy onderskeiding van die Ding an sich en die Erscheinung: sedelikheid hoort tot die wese van die mens (maar dan ook net van die mens), waaruit ons kan konkludeer dat vryheid ewe wesenlik van die mens moet wees. As Erscheinung is die mens en wat ons van hom kan waarneem, aan die wet van oorsaaklikheid onderhewig, net so goed soos enige ander nie-menslike verskynsel. By die mens, net soos by alle ander dinge, is dit egter betekenisloos om van 'n verskynsel te praat sonder dat daar iets is wat verskyn, sodat ons moet aanvaar dat behalwe Erscheinung die mens ook Ding an sich is. Die denkkategorieë (waaronder die kategorie van oorsaaklikheid) is egter nie op die Ding an sich van toepassing nie en dit stel Kant in staat om te besluit: ..... so kann ich mir doch die Freiheit denken, d.i. die Vorstellung davon enthällt wenigstens keinen Widerspruch in sich ..." (KrV, B XXVIII). "Ich muszte also 
das Wissen autheben, um zum Glauben Platz zu bekommen . $(\mathrm{KrV}, \mathrm{B} X \mathrm{XX})$.

Kant se gebruik van die woord „Glauben" is hier van besondere betekenis: die onderskeiding van Ding an sich en Erscheinung maak dit moontlik om die teoretiese (wetenskaplike) rede van die praktiese rede te onderskei. Die teoretiese rede het te doen met wat is - die praktiese met wat behoort te wees; die teoretiese rede wil die werklikheid ken - die praktiese wil daarop ingryp en dit volgens norme verander. Die absoluut en algemeen geldende norm is die sedewet, die pligsgebod of kategoriese imperatief (per slot van rekening vir Kant drie terme vir dieselfde saak), wat a priori in die praktiese rede self grond. Die uiteindelike objek van die praktiese rede is die goeie en die slegte, maar wat goed en sleg is, word deur die sedewet bepaal. Die sedelike waarde van ons hele praktiese lewe hang af van die bepaaldheid daarvan deur die sedewet (Kritik der praktischen Vernunft, A 126). In die totale opset van ons bestaan, waarin Kant die breë maar fundamentele onderskeiding van die teoretiese en die praktiese mak, het die praktiese lewe ongetwyfeld die primaat, omdat die teoretiese sonder die praktiese nie moontlik is nie en die teoretiese uiteindelik altyd in die praktiese uitmond (KpV, A 216 sqq.). Die praktiese bestaan, waar dit wesenlik om die sedelike gaan, is die objek van studie van die praktiese rede. Wanneer die praktiese rede egter die sedelike handeling en alles wat dit meebring en impliseer, sistematies wil uiteensit, word die praktiese rede gedwing tot die aanvaarding van teoremas wat as die singewende grond van die sedelikheid dien, maar wat self nie teoreties (d.w.s. wetenskaplik) bewysbaar is of sinvol gemaak kan word nie. Wanneer ons dit verbind met Kant se woord "Glauben" wat ons hierbo aangehaal het, kan ons van die teoremas praat as 'n geloofsgrondslag wat aanvaar moet word: geloof, omdat ons dit wetenskaplik nie kan bewys nie; en ons moet dit aanvaar, omdat daarsonder ons sedelike denke (maar ook ons sedelike lewe as praktiese aktualiteit) in die lug sou hang en sinloos sou wees. Hierdie teoremas noem Kant die postulate van die suiwere praktiese rede en onderskei drie van hulle ( $\mathrm{KpV}, \mathrm{A} 220$ sqq.):

1. Die onsterflikheid van die siel: die gehoorsaamheid aan die sedewet impliseer die eis van die volmaaktheid van die mens. Die mens se werklike toestand is egter sodanig dat die bose altyd van krag bly, wat beteken dat die volmaaktheid nog nie bereik is nie. Om die volmaaktheid te kan bereik is dit noodwendig dat die oneindige voortbestaan van die siel aanvaar moet word.

2. Die bestaan van God: die sedelik goeie handeling is die handeling wat geskied in gehoorsaamheid aan die sedewet wat in die vorm van die kategoriese imperatief na ons toe kom. nl. die 
onvoorwaardelike eis dat ons die goeie moet doen ter wille van die goeie en nie ter wille van een of ander gevolg nie (geluk, nut, ens.). Desnieteenstaande is dit ' $n$ onlosmaaklike deel van ons sedelike gevoel dat iemand wat in gehoorsaamheid aan die sedewet lewe, gelukkig sal wees. Ons kan ook sê dat geluk die natuurlike gevolg van die sedelik goeie lewe is. Dit is egter ons daaglikse ervaring dat dit nie die geval is nie; daar is ' $n$ kloof tussen die sedelik goeie lewe en die natuurlike gevolg daarvan, $\mathrm{nl}$. geluk. Om die sedelik goeie lewe sinvol te maak is dit noodsaaklik dat ons die bestaan van God moet aanvaar - God as die hoogste wese wat die kloof tussen die goeie lewe en die natuurlike gevolg daarvan oorbrug. m.a.w. wat die goeie lewe beloon met geluk.

3. Vryheid: die belangrikste van die drie postulate is vryheid, wat vir Kant dieselfde is as outonomie. Ons het reeds hieroor gepraat. Hier wil ons net stel dat vryheid so selfevident 'n noodsaaklike voorwaarde vir sedelikheid is, dat ' $n$ mens dit vreemd vind dat Kant vryheid as ' $n$ postulaat stel. Hy doen dit omdat daar vir hom net een van twee moontlikhede is: óf vryheid is 'n objektief gegewene (en dus Erscheinung) en dan is dit voorwerp van die teoretiese denke; dit sluit egter vryheid as moontlikheid uit, omdat die voorwerp van die teoretiese denke, die Erscheinung, aan 'n streng universeel geldende meganiese kousaliteit onderworpe is: Of vryheid hoort tot die transendente wêreld, die wêreld van die Ding an sich, wat nie teoreties kenbaar is nie en dus nie aan oorsaaklikheid onderworpe is nie; dit maak vryheid moontlik, maar dan kan ons nie wetenskaplike bewysbaarheid vir vryheid opeis nie, maar moet ons dit as noodwendige postulaat van die suiwere praktiese rede handhaaf.

Op hierdie punt wil ons nou oorgaan na die ideologiese denke van die E19 om die invloed van Kant in enkele hoofpunte na te gaan. Dit is heeltemal onmoontlik om die ideologiese denke van die E19 te verstaan as ons nie baie meer faktore as net die filosofie van Kant in aanmerking neem nie. Sommige van hierdie faktore is ook baie belangriker as die filosofie van Kant, bv. die filosofie van Hegel, die Franse Revolusie en die politieke onrus wat daaruit voortgevloei het, die ekonomiese, sosiale en politieke toestande waaronder veral die proletariaat gebuk gaan en so meer. Sonder die invloed van die filosofie vah Kant is die ideologiese denke van die E19 egter ook nie histories behoorlik verstaanbaar nie.

Ons wil hier net op twee aspekte wys:

1. Kant se Kopernikaanse wending het die denkmodel van die E19 geword. Die E19 was besiel met ' $n$ drif tot ontmaskering en die ontmaskering neem die vorm van ' $n$ omkering of ' $n$ reduksie aan: 
die kultuur in die algemeen, die denke, die godsdiens, kuns, sosiale verhoudinge, spesifiek menslike kenmerke ens. word as skyn ont-. masker, terwyl die ontmaskering die ware werklikheid blootlê. Anders gestel: kultuur ens. word gereduseer tot iets anders wat dan as die ware werklikheid geld. In terme van Karl Marx gestel: kultuur ens. is die bowebou, wat op iets anders as die onderbou berus. Hierdie ware werklikheid is nie net die fondament nie, maar is eintlik die verklaringsgrond, sodat die kultuur ens. te voorskyn tree as niks anders nie as die besondere ware werklikheid wat aangebied word. So word alle verskynsels by die materialisme tot epiphenomene, neweverskynsels van die ware werklikheid, $\mathrm{nl}$. materie en sy wetmatige prosesse gemaak; in die Darwinisme word kultuur ens. gereduseer tot fisiologiese prosesse wat in terme van evolusie verklaar word; by Freud is die seksuele libido die allesverklarende grondslag. Kierkegaard keer Hegel om: nie objektiviteit nie, maar subjektiviteit is die waarheid; nie die algemene nie, maar die eksistensie van die enkeling. Ook Marx keer Hegel om: nie die bewussyn bepaal die syn nie, maar die syn die bewussyn; die allesverklarende onderbou is die produksiemiddele. produksiekragte en produksieverhoudinge. Feuerbach: God het nie die mens na die beeld van God geskep nie. maar die mens het God na die beeld van die mens geskep; die geheim van die teologie is die antropologie.

2. Hierbo het ons van die ware werklikheid gepraat. Die ware werklikheid is ' $n$ metafisiese entiteit, die finale, allesfunderende en allesverklarende prinsipe en die grond van alles wat bestaan. Die klassieke metafisiese sisteme voor Kant (bv. Descartes en Spinoza). het nie net op wetenskaplikheid aanspraak gemaak nie, maar juis omdat hulle kennis van die ware werklikheid aangebied het, was die metafisika die koningin van die wetenskappe. Met sy fundering van wetenskaplike kennis, wat tegelykertyd die grense van teoretiese. kennis omlyn, slaan Kant die bodem uit die klassieke metafisika, omdat die metafisika die grense van moontlike ervaring oorskry en daarmee enige wetenskaplike kennis onmoontlik maak. Dit was die nekslag van hierdie soort metafisika.

Kant self verwerp egter nie die metafisiese of die metafisika nie. Die kritiek op die metafisika lewer hy in sy Kritik der reinen Vernunft, maar juis in hierdie werk praat hy op talle plekke van die metafisika wat vir die mens noodsaaklik is en wat tot die natuur van die menslike rede behoort. Hierdie metafisika kan egter nie op die teoretiese rede gebou word nie en moet op die praktiese rede gebou word. Hieruit vloei sy leer van die postulate. Hierdie standpunt word deur die ideologieë, wat in die E19 ontspring, op hulle eie manier aanvaar en uitgebou. Ons toon dit kortliks aan veral in die filosofie van Karl Marx²): 
2.1. Saam met die hele E19 is Marx (in navolging van Kant) anti-metafisies gesind. Die ware werklikheid wat die allesbepalende en allesverklarende grondslag is, is nie ' $n$ transendente werklikheid nie, maar selfevident en in sy effektiewe bestaan empiries aantoonbaar. So moet elkeen wat nie totaal deur sy bourgeois ideologie verblind is nie, sien dat ons in 'n verkeerde wêreld leef, m.a.w. dat ons wêreld in al sy aspekte en geledinge fundamenteel verkeerd is en dat hierdie verkeerdheid berus op verkeerde produksieverhoudinge, wat impliseer dat ekonomiese kragte die grondslag van alles is.

2.2. Primêr is nie die teoretiese nie, maar die praktiese. Van primêre belang is nie om die wêreld te ken nie, maar om dit te verander. Wetenskap is belangrik en noodsaaklik, maar die uiteindelike doel van die wetenskap moet wees om die revolusie en die nuwe wêreld wat uit die revolusie gebore sal word, te dien en te lei.

2.3. Kant stel streng wetenskaplik-metodiese eise aan die praktiese filosofie (waarvan die etiek die belangrikste is), maar sin en rigting word aan die handeling sowel as aan die denke van die praktiese rede deur die postulate gegee, wat 'n praktiese en nie 'n teoretiese aangeleentheid is nie. Op dieselfde wyse kry die ware werklikheid in die E19se ideologiese denke primêr 'n praktiese betekenis. Kant se onderskeiding van Ding an sich en Erscheinung met die gepaardgaande gedagte van die teoretiese onkenbaarheid van die Ding an sich word in sy eie tyd reeds betwis en algaande steeds meer afgetakel. Dat die ware werklikheid teoretiese (wetenskaplik) onkenbaar is, gee Marx dus nie toe nie, maar die praktiese betekenis daarvan staan daarom nie minder op die voorgrond nie. Op die terrein van die filosofie en die ekonomie het Marx hoogstaande wetenskaplike werk gelewer, maar dit het alles in diens van die opperste beginsel, $\mathrm{nl}$. die ekonomiese bepaaldheid van die bestaan van die mens, gestaan. Die ware werklikheid, die verklaringsbeginsel is by Marx net soos by Kant ' $n$ praktiese aangeleentheid: dit berus op 'n waardevoorkeur, dit eis eksistensiële aanvaarding en roep die mens tot ' $n$ bepaalde lewenswyse en uitgesproke voor- en afkeure op. Dit is ' $n$ tendens wat ons in die E19 opmerk ook by baie wat oortuig is dat hulle met suiwer wetenskaplike werk besig is: in die Evolusionisme word bv. die betekenis van die evolusiteorie na elke faset van die mens se lewe deurgetrek en die psigologie van Sigm. Freud het 'n groter revolusie in die praktiese lewe van die Westerse mens as in die wetenskap gebring.

In meer byderwetse terme kan ons só afsluit:

Die mens is vryheid omdat hy ' $n$ onvoltooide wese is wat in ' $n$ oop wêreld met oop horisonne moet bestaan. Die voorwaarde vir die moontlikheid van so'n menslike bestaan is dat die mens vir 
homself ' $n$ staanplek in sy wêreld moet kan vind. Hierdie staanplek maak dit moontlik dat hy sy lewe kan ontwerp en op ' $n$ sinvolle wyse kan lei. Hierdie staanplek vind hy in hoogste waardes en laaste gronde, wat nie ' $n$ wetenskaplike aangeleentheid is nie en ook nie van bloot empiriese oorsprong is nie, maar ' $n$ aangeleentheid van eksistensiële beslissing en diepste oortuiging. Dit is bepalend vir die hele lewe van die mens en is ook die voorwetenskaplike grond en motivering vir wetenskaplike arbied.

Tot sover sou Kant met hierdie formulering saamgaan, omdat dit ruimte bied vir, klop met en in 'n sekere sin voortsetting is van sy geweldige hoë waardering van die menslikheid van die mens, sy beklemtoning van die onskendbaarheid van die waardigheid van die mens en sy eis van die-onvoorwaardelike gehoorsaamheid aan die sedewet.

Waarmee Kant nie sou kon saamgaan nie, is wat die ideologieë daarvan gemaak het, $\mathrm{nl}$. die allesoorheersende posisie van 'n bepaalde waarde (of samehangende groep waardes) wat die grond vorm vir ' $n$ revolusionêre leer met ' $n$ praktiese doelwit, $n l$. die omverwerping van die bestaande orde ten gunste van 'n nuwe orde; wat Kant sou afkeur, is die eksklusiviteit van die ideologie, die geweld wat meesal daarmee gepaard gaan, maar meeste van alles die skending van die menslike waardigheid soos dit in elke individu verteenwoordig word en die ontkenning van die universele, onvoor. waardelike geldigheid van die sedewet.

Tradisioneel het die wetenskap, by uitstek die filosofie, in 'n ivoortoring (Bacon) van verhewe en ireniese afgesonderdheid sy woonplek gehad. Vandag is die filosofie nie meer 'n teruggetrokke. goedgemanierde, rustig toekykende edelman nie, maar heel dikwels $n$ revolusionêre straatbetoger en anargis of ' $n$ konstabel wat verbete veg om orde op straat te handhaaf. Die man wat meer as enigiemand anders die filosofie op straat gebring het en van hom in revolusionêre betoger gemaak het, was Karl Marx, maar Immanuel Kant het die deur van die adellike toring oopgemaak. Dit moet ons in die filosofie van Kant raaksien om sodoende ook die ideologiese denke beter te verstaan. Maar dit was nooit Kant se bedoeling dat die filosofie op straat ooit sy adellike inbors, sy verfynde maniere, sy hoë lewensideaal en sy onkreukbare eerbaarheid moet prysgee nie. Trouens, dit is en bly die gees en die wese van Kant se praktiese filosofie. Ons moet erken dat Kant reg was om die deure van die toring oop te maak; maar die geskiedenis het ons geleer wat die gevare van die straat is. Ons kan nie ' $n$ beter eer aan die nagedagtenis van Kant bring as om sy filosofie te leer ken soos wat hy dit self geleer en bedoel het nie. 
1). C1. J. Lamprecht. Wetenskap en Ideologie, M.A.-verhandeling in die wysbegeerte, Universiteit van Pretoria, 1974; J. Barion, Ideologie, Wissenschaft, Philosophie, H. Bouvier, Bonn, 1966; H. Barth, Wahtheit und Ideologie. Manesse Verlag, Zürich, 1945; Karl Mannheim, Ideology and Utopia, Kegan Paul, London, 1940. In hierdie werke word verwysings na 'n uitgebreide literatuur gevind.

2) Soos bekend is, het ,ideologie" vir Marx die betekenis van 'n "noodwendig vals bewussyn". Ideologie is die denke (wetenskaplik en "andersins) van die bourgeoisie, wat in sy bestaan en sy denke die resultaat is van die vals on verkeerde wêreld wat op sy beurt voortvloei uit die verkeerde produksieverhoudinge, $\mathrm{nl}$. die verhouding van die besitlose proletariaat wat deur hulle gedwonge loonarbeid in 'n staat van selfvervreemding en slawerny verkeer, tot die kapitalistiese besitters en uitbuiters. nl. die bourgeoisie. Marx gebruik die filosofie nie net om die wêreld van sy tyd te ken nie, maar ook die verkeerdheid daarvan aan te toon. Die filosofie moet nie net 'n teoretiese grondslag vir die komende revolusie van die proletariaat gee nie, maar ook die leiding aan die revolusie gee. So'n filosofie is vir Marx geen ideologie nie, maar juis die ware wetenskap. Ons gebruik die woord "ideologie" in sy moderne betekenis, dus nie soos Marx dit gebruik het nie, maar soos ons dit in die inleiding van hierdie artikel uiteengesit het. 